\title{
Insulin Secretion and Metabolism during the Perinatal Period in the Rat
}

\author{
EVIDENCE FOR A PLACENTAL ROLE IN FETAL HYPERINSULINEMIA
}

\author{
Françoise R. Sodoyez-Goffaux, Jean C. Sodoyez, and Claudine J. De Vos, \\ Departments of Pediatrics and of Internal Medicine, University of Liege, B-4020 \\ Liege, Belgium
}

A B S T RACT To better understand why plasma immunoreactive insulin (IRI) concentration is high in the rat fetus during the last $3 \mathrm{~d}$ of gestation and why fetal hyperinsulinemia abruptly subsides after birth, insulin secretion and metabolic clearance rates were estimated in fetuses and nursed pups.

Intravenously injected $\left.{ }^{125} \mathrm{I}\right]$ monoiodoinsulin was cleared from the plasma of prematurely delivered pups at least as rapidly as from that of 7- to 10-d-old pups, suggesting that fetal hyperinsulinemia is not a result of slow clearance of the hormone. The fetal liver bound $35 \%$ of the injected label within $3 \mathrm{~min}$, and binding was saturable. The uptake of radioactivity by the fetal kidney was nonsaturable and much lower than that of adult rat kidney.

Isolated fetal islets were already reactive to glucose on the 19th d of gestation. Pancreatic insulin secretory capacity was estimated by measuring $(a)$ the insulin release of isolated islets incubated in the presence of $2.8 \mathrm{mM}$ glucose, $(b)$ the insulin content of the same islets, and $(c)$ the total insulin extracted from the pancreas, using the formula $(a \times c) / b$. $2 \mathrm{~d}$ before birth, the pancreatic insulin secretory capacity was high, accounting for fetal hyperinsulinemia. It was even higher after birth, not accounting for the postnatal decrease in plasma IRI concentration.

Pups delivered by caesarian section $1 \mathrm{~d}$ before term exhibited a brisk decrease in plasma IRI concentration when the cord was cut. By contrast, if the feto-placental unit was removed from the dam, maintaining fetal

Parts of this work were presented at The 13th Annual Meeting of the European Association for the Study of Diabetes, September 1977 (1977. Diabetologia. 13: 433. [Abstr.]), and at The 38th Annual Meeting of the American Diabetes Association, June 1978 (1978.Diabetes. 2[Suppl. 27]: 462. [Abstr.]).

Received for publication 19 May 1978 and in revised form 18 December 1978. blood circulation through the placenta, fetal plasma IRI concentration remained as high as in utero. These experiments suggest that a placental factor stimulates fetal insulin secretion. After birth, when the cord is cut, insulin secretion is rapidly turned off, and the pups switch from a state of unlimited fuel supply by the mother to a state of fuel saving.

\section{INTRODUCTION}

Fetal hyperinsulinism has been documented during the last days of gestation in the rat. After birth, plasma immunoreactive insulin (IRI) ${ }^{1}$ concentration decreases towards values similar to those found in adult rats (1-3). Little is known about the mechanism whereby hyperinsulinemia is brought about at the end of gestation and whereby it subsides after birth. Because plasma insulin concentration reflects the equilibrium between hormone output by the pancreatic islets and uptake by the peripheral tissues, a valid understanding of insulin metabolism requires that both parameters be concomitantly studied. In this paper we report our estimates of the rates of pancreatic insulin secretion and peripheral tissue uptake during the perinatal period, and suggest that the placenta plays a key role in fetal insulin economy.

\section{METHODS}

Pregnant rats. Female albino rats weighing 230-260 g were caged overnight with a male so that the duration of pregnancy was known with a 12 -h error.

Fetal and neonatal blood glucose and plasma IRI concentration. Blood was collected after decapitation of the pups. Blood glucose concentration was measured by the hexokinase method and plasma IRI concentration by the double antibody

\footnotetext{
${ }^{1}$ Abbreviation used in this paper: IRI, immunoreactive insulin.
} 
method (4), using a rat insulin standard (lot R171, Novo Research Industry, Copenhagen, Denmark).

Pancreatic insulin secretory capacity. The pancreas of the pups was rapidly removed and trimmed of extraneous tissues. One to three pancreases were homogenized in $2 \mathrm{ml}$ of acid ethanol $(750 \mathrm{ml}$ absolute ethanol, $15 \mathrm{ml} 12 \mathrm{~N} \mathrm{HCl}$, and $235 \mathrm{ml}$ $\mathrm{H}_{2} \mathrm{O}$ ). The others were transferred into $2 \mathrm{ml}$ of Hanks' solution, to which $1 \mathrm{mg}$ of collagenase (Clostridium histolyticum, grade II, lot 1406317, C. F. Boehringer and Sons, Mannheim, West Germany) was added (5). After very mild digestion at $37^{\circ} \mathrm{C}$, the islets were washed three times, and the final suspension was examined with a dissecting microscope. The fetal islets, particularly those obtained after $19 \mathrm{~d}$ of gestation, were very small and best seen on a black background. They were freed of extraneous tissues by microdissection, picked with a wire loop, and transferred to Erlenmeyer flasks containing $2 \mathrm{ml}$ of ice-cold incubation medium kept under a $95 \% \mathrm{O}_{2}, 5 \% \mathrm{CO}_{2}$ atmosphere. The incubation medium consisted of KrebsRinger bicarbonate buffer supplemented with $10 \mathrm{mg} / \mathrm{ml}$ crystallized bovine serum albumin (Sigma Chemical Co., St. Louis, Mo.) and 2.8 or $16.7 \mathrm{mM}$ glucose. Each vial received 10 islets and was incubated for $60 \mathrm{~min}$ at $37^{\circ} \mathrm{C}$ in a metabolic shaker. At the end of the incubation, the medium was aspirated through a Millipore filter holder (Millipore Corp., Bedford, Mass.) equipped with a nylon filter of 5-micrometer pore size which was selected because it retained cells and did not adsorb insulin. The cell-free medium was stored frozen at $-20^{\circ} \mathrm{C} .10$ additional islets were directly transferred to a Potter-Elvehjem homogenizer containing $2 \mathrm{ml}$ of acid ethanol. After homogenization and extraction for $24 \mathrm{~h}$ at $4^{\circ} \mathrm{C}$, the acid-ethanol extracts were centrifuged and the supernates stored at $-20^{\circ} \mathrm{C}$. After appropriate dilution of the medium or of the extracts, IRI concentration was measured. Knowing $(a)$ the amount of insulin released by one islet, $(b)$ the amount of insulin contained in one islet, and $(c)$ in the pancreas, the insulin secretory capacity of the whole pancreas was calculated according to the equation $(a \times c) / b$.

[ $\left.{ }^{125} I\right] M o n o i d o i n s u l i n$ metabolism. Pure, carrier-free $\left[{ }^{125} \mathrm{I}\right]-$ monoiodoinsulin was prepared as previously described (6), and $0.006 \mu \mathrm{Ci} / \mathrm{g}$ body wt were injected into $1-\mathrm{d}$ preterm fetuses and into 7- to 10-d-old pups. Unanesthetized preterm pups were injected into the umbilical vein with a Hamilton microsyringe. To prevent bleeding from the punctured vessel, the cord was ligated and cut immediately after the injection. Under light anesthesia (Nembutal [Abbott Laboratories, North Chicago, Ill.] $25 \mathrm{mg} / \mathrm{kg}$ i.p.), older pups were injected through a 30-g needle inserted into the internal saphenous vein. At selected times, both groups were sacrificed, blood was collected, and the liver and kidneys were rapidly removed. Serum samples were gel chromatographed on a $60 \times 1.2-\mathrm{cm}$ G50 F Sephadex (Pharmacia Fine Chemicals, Div. of Pharmacia Inc., Piscataway, N. J.) column equilibrated and developed with $1 \mathrm{M}$ acetic acid. Other aliquot samples were mixed with an excess of guinea pig anti-insulin serum ${ }^{2}$ and an amount of rabbit anti-guinea pig serum sufficient to precipitate all the guinea pig gamma globulins. After $4 \mathrm{~d}$ of incubation at $4^{\circ} \mathrm{C}$, the immune complexes were collected by microfiltration and their radioactivity was measured. The radioactivity of the liver, kidneys, and carcass was also measured. Counts recovered in the serum, liver, kidneys, and carcass represented $85-90 \%$ of the injected radioactivity. Some rat fetuses and pups received [ $\left.{ }^{125} \mathrm{I}\right]$ monoiodoinsulin mixed with native insulin, $0.4 \mu \mathrm{g} / \mathrm{g}$ body wt.

${ }^{2}$ A generous gift of Professor P. H. Wright, Indiana University, Indianapolis, Ind.

\section{RESULTS}

As illustrated in Fig. 1, fetal plasma IRI concentration rose from $140 \pm 52 \mu \mathrm{U} / \mathrm{ml} 3 \mathrm{~d}$ before term to a maximum of $524 \pm 334 \mu \mathrm{U} / \mathrm{ml} 2 \mathrm{~d}$ before term. Plasma IRI concentration was $91 \pm 29 \mu \mathrm{U} / \mathrm{ml}$ at birth and stabilized at $56 \pm 15 \mu \mathrm{U} / \mathrm{ml} 1 \mathrm{~h}$ after birth. Blood glucose concentration slowly rose from $52 \pm 14 \mathrm{mg} / 100 \mathrm{ml} 3 \mathrm{~d}$ before term to $87 \pm 14 \mathrm{mg} / 100 \mathrm{ml}$ at birth; decreased during the first hours of extrauterine life, when the pups were fasting; and later increased, when the pups were nursed. Thus a marked hyperinsulinemia occurred during the last $3 \mathrm{~d}$ of gestation, but fetal blood glucose concentration did not correlate with plasma IRI concentration.

Islets of Langerhans were isolated at various stages of development and incubated in the presence of glucose at the concentration of 2.8 or $16.7 \mathrm{mM}$, the former being close to the blood concentration in utero. As shown in Fig. 2, the rate of insulin secretion in the presence of low glucose concentration steadily increased from $3 \mathrm{~d}$ before term to a few hours after spontaneous delivery. The mean insulin release of islets isolated from 1-d-old pups was smaller than that of newborn pups, but the difference did not reach the level of statistical significance. At a high concentration, glucose proved an effective stimulus of insulin secretion, even for islets isolated on the 19th d of gestation.

As shown in Table I, the estimated IRI secretory capacity was high in fetuses $2 \mathrm{~d}$ before term but much higher in 24- to 48-h-old pups. To account for rapid body growth, these values of secretory capacity should be corrected for body mass. An estimate of the

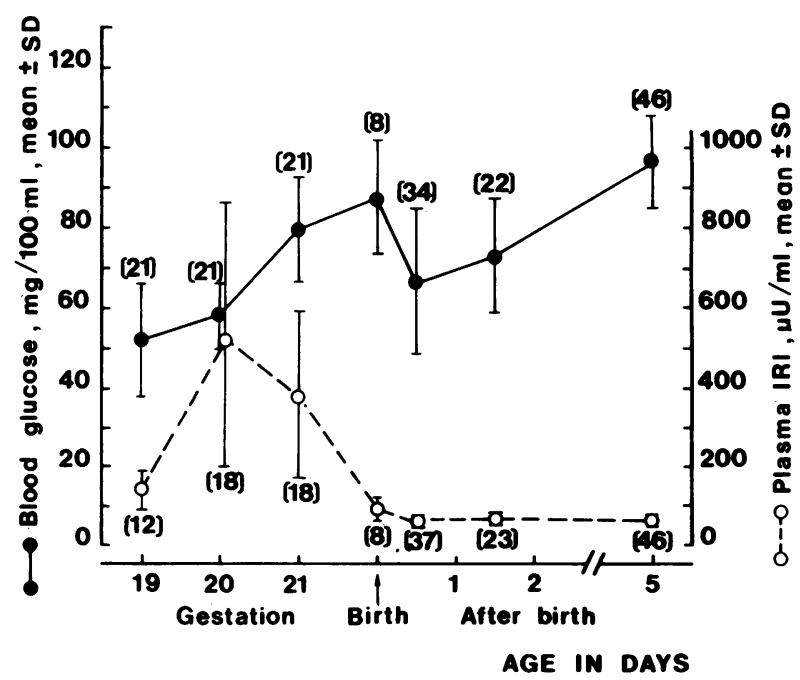

Figure 1 Blood glucose and plasma IRI concentrations during the perinatal period. Fig. 1 shows mean $\pm S D$. The number of observations is shown in parentheses. 


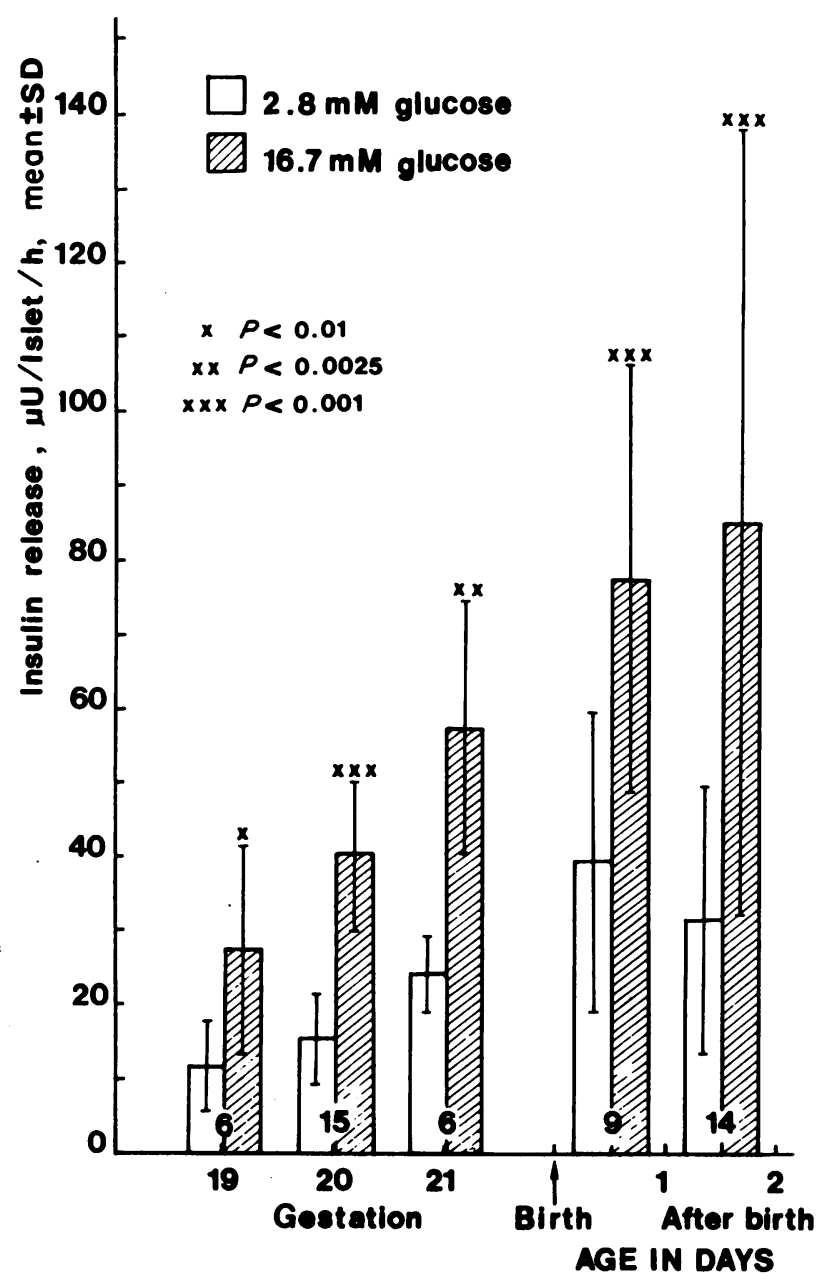

FIGURE 2 IRI release by isolated islets during the perinatal period. Each column represents the mean of the number of observations. The number is indicated at each column base. The vertical bars represent $\pm 1 \mathrm{SD}$. Statistical analysis was performed with paired $t$ test.

"relative secretory capacity" was calculated by dividing the absolute insulin secretory capacity by the body weight. The relative secretory capacity was high for preterm fetuses, easily accounting for high plasma insulin concentration. It was higher in 24- to 48-h-old pups, not accounting for the postnatal decrease in plasma insulin concentration. This observation indicates that the perinatal variations of plasma insulin concentration were brought about by extrapancreatic factors and not by intrinsic changes of the islets.

Table II and Fig. $3 \mathrm{~A}$ show the evolution of serum total radioactivity and of [ $\left.{ }^{125} \mathrm{I}\right] \mathrm{monoiodoinsulin}$ and free ${ }^{125} I^{-}$concentration after an intravenous bolus injection of labeled hormone alone or mixed with an excess of native insulin into preterm fetuses. $1 \mathrm{~min}$ after the injection of the tracer plus insulin, undamaged $\left[{ }^{125} \mathrm{I}\right]-$
TABLE I

Estimates of the Pancreatic Insulin Secretory Capacity*

\begin{tabular}{|c|c|c|}
\hline & $\begin{array}{c}2 \mathrm{~d} \text { before term } \\
(n=26)\end{array}$ & $\begin{array}{c}24-48 \mathrm{~h} \text { after birth } \\
(n=19)\end{array}$ \\
\hline \multicolumn{3}{|c|}{ IRI output, $\mu U / h /$ islet $(a)$} \\
\hline $2.8 \mathrm{mM}$ glucose & $12.7 \pm 7.2 \ddagger$ & $34.4 \pm 20.3$ \\
\hline $16.7 \mathrm{mM}$ glucose & $33.1 \pm 13.1$ & $90.5 \pm 42.9$ \\
\hline \multicolumn{3}{|l|}{ Extractable IRI, } \\
\hline$\mu$ Ulislet $(b)$ & $319 \pm 142$ & $1,143 \pm 345$ \\
\hline mU/pancreas $(c)$ & $52.1 \pm 12$ & $325 \pm 80$ \\
\hline \multicolumn{3}{|c|}{$\begin{array}{l}\text { Total IRI secretory capacity } \\
\qquad(a \times c) / b, m U / h / \text { pancreas }(d)\end{array}$} \\
\hline $2.8 \mathrm{mM}$ glucose & $2.32 \pm 1.65$ & $11.02 \pm 6.80$ \\
\hline $16.7 \mathrm{mM}$ glucose & $5.96 \pm 3.07$ & $25.70 \pm 14.00$ \\
\hline Body weight, $g(e)$ & $3.60 \pm 0.19$ & $6.96 \pm 0.52$ \\
\hline \multicolumn{3}{|c|}{$\begin{array}{l}\text { Relative IRI secretory capacity } \\
\quad(\mathrm{d} / \mathrm{e}), \mathrm{mU} / \mathrm{h} / \mathrm{g}\end{array}$} \\
\hline $2.8 \mathrm{mM}$ glucose & $0.64 \pm 0.44$ & $1.49 \pm 0.98$ \\
\hline $16.7 \mathrm{mM}$ glucose & $1.66 \pm 0.84$ & $3.85 \pm 1.96$ \\
\hline
\end{tabular}

* Mean \pm SD.

$\downarrow$ All the values of the left column are statistically different from their counterpart in the right column.

monoiodoinsulin accounted for $74 \%$ of the total serum radioactivity. After the injection of the tracer alone, total serum radioactivity was much lower $(4,879$ vs. $11,376 \mathrm{cpm} / 100 \mu \mathrm{l})$ and undamaged [ $\left.{ }^{125} \mathrm{I}\right]$ monoiodoinsulin accounted for only $40 \%$ of the total. Because the presence of native insulin is not expected to modify the distribution of $\left[{ }^{125} I\right]$ monoiodoinsulin into the plasma and extracellular fluid compartments, it must be concluded that, during the lst min, a considerable proportion of the injected label had been trapped into a saturable compartment, most likely, as shown below, into the receptor compartment. Between 1 and 9 min after the injection of $\left[{ }^{125} \mathrm{I}\right]$ monoiodoinsulin alone, undamaged $\left[{ }^{125}\right.$ I] monoiodoinsulin concentration decreased in a semilogarithmic fashion with a period of $2 \mathrm{~min}$. The concomitant injection of native insulin markedly retarded the clearance of the tracer. Essentially similar results were obtained in older pups (Table III, Fig. 3B). Comparison of the two age groups allows us to conclude that the metabolic clearance rate of insulin was certainly not slower in the preterm fetuses.

After Sephadex chromatography, several radioactive components were isolated (Fig. 4), respectively eluted in the void volume (peak 1 , unidentified), in the volume of undamaged [ ${ }^{125} \mathrm{I}$ ] monoiodoinsulin (peak 2, immunoreactive $\left.{ }^{[125} \mathrm{I}\right]$ monoiodoinsulin), in volumes intermediate between those of peak 2 and salt (unidentified small molecular weight peptides), in the volume of salt (peak 3, identified by several criteria not 
TABLE II

Serum Radioactivity after Intravenous Injection of [ ${ }^{125}$ ] $]$ Monoiodoinsulin Alone or Mixed with an Excess of Native Insulin into 1-d Preterm Pups*

\begin{tabular}{|c|c|c|c|c|c|c|c|}
\hline \multirow[b]{3}{*}{$\begin{array}{l}\text { Sampling } \\
\text { time }\end{array}$} & \multicolumn{4}{|c|}{ [ $\left.{ }^{125} 1\right]$ Monoiodoinsulin alone } & & & \\
\hline & \multicolumn{3}{|c|}{$\begin{array}{l}\left.\left[{ }^{[25}\right]\right] \text { Monoiodoinsulin } \\
\text { as identified by }\end{array}$} & \multirow[b]{2}{*}{ 125!- } & \multicolumn{3}{|c|}{$\left[{ }^{125} \mathbf{I}\right]$ Monoiodoinsulin + native insulin } \\
\hline & $\begin{array}{l}\text { Total } \\
\text { radio- } \\
\text { activity }\end{array}$ & $\begin{array}{l}\text { Immunopre- } \\
\text { cipitation }\end{array}$ & $\begin{array}{l}\text { Gel chroma- } \\
\text { tography }\end{array}$ & & $\begin{array}{l}\text { Total } \\
\text { radio- } \\
\text { activity }\end{array}$ & $\begin{array}{l}\left.\left[{ }^{125}\right]\right] \text { Monoiodoinsulin } \\
\text { as identified by } \\
\text { gel chromatography }\end{array}$ & ${ }^{123} \mathbf{I}^{-}$ \\
\hline $\min$ & \multicolumn{7}{|c|}{$c p m / 100 \mu l$} \\
\hline 1 & 4,879 & 1,766 & 2,005 & NDł & 11,376 & 8,440 & ND \\
\hline 3 & 2,882 & 862 & 953 & 29 & 7,911 & 5,024 & ND \\
\hline 6 & 1,545 & 249 & 331 & 126 & 4,623 & 2,954 & ND \\
\hline 9 & 1,137 & 99 & ND & 216 & 2,917 & 1,312 & ND \\
\hline 12 & 1,348 & ND & ND & 333 & 2,662 & 1,193 & ND \\
\hline
\end{tabular}

* All values given are counts per minute per 100 microliters.

† Nondetectable.

described here as free $\left.{ }^{125} \mathrm{I}^{-}\right)$, and finally in a volume larger than that of salt (peak 4, also identified by various criteria as $\left[{ }^{125} \mathrm{I}\right]$ monoiodotyrosine). Free iodide was the only serum radioactive component of which the plasma concentration increased with time (Fig. 4, Tables II and III).

In both groups of animals, iodide production was suppressed by the concomitant injection of native insulin. Because native insulin competes with $\left.{ }^{[25} \mathrm{I}\right]-$ monoiodoinsulin for insulin binding and degradation
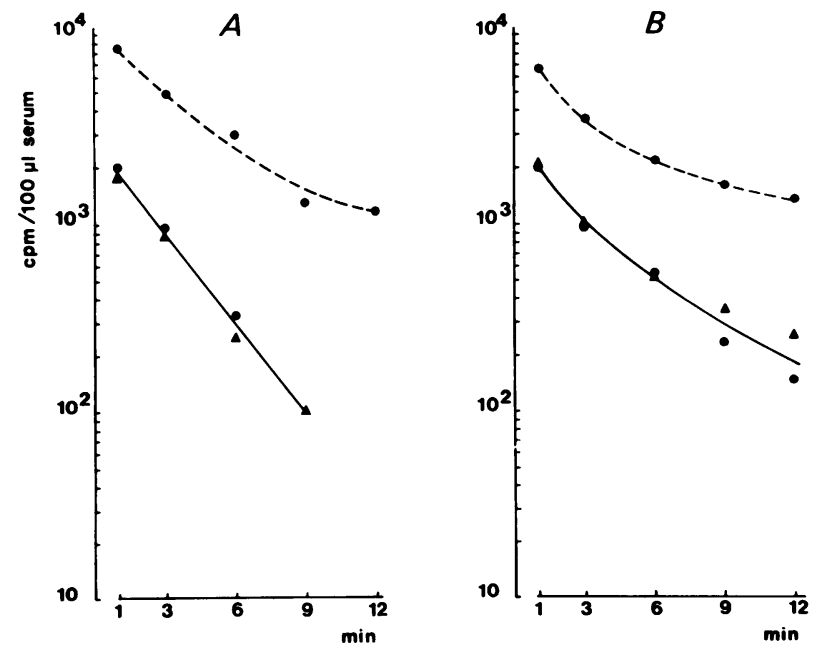

FIGURE 3 Disappearance rate of serum [ $\left.{ }^{125} \mathrm{I}\right]$ monoiodoinsulin after an intravenous bolus injection of the labeled hormone alone or mixed with an excess of native insulin into fetuses and nursed pups. [125I]monoiodoinsulin alone (solid line) or mixed with native insulin (dashed line) was injected into the umbilical vein of $1-d$ preterm fetuses (A) or the internal saphenous vein of 7- to 10-d-old pups (B). Serum [ ${ }^{125}$ I]monoiodoinsulin concentration was determined by immunoprecipitation $(\boldsymbol{\Delta})$ or by chromatography $(\boldsymbol{O})$. sites but not for dehalogenase activity, the rate of ${ }^{125} \mathrm{I}^{-}$production is probably related to $\left[{ }^{125} \mathrm{I}\right]$ monoiodoinsulin catabolism. Comparison of Tables II and III shows that the plasma concentration of ${ }^{125} \mathrm{I}^{-}$increased faster in pups than in fetuses.

As seen in Fig. 5A, a sizable portion of the radioactivity injected into preterm fetuses was rapidly bound to the liver ( $31 \%$ after $1 \mathrm{~min}$ and $37 \%$ after $3 \mathrm{~min}$ ). By contrast, kidney radioactivity remained low (3\%). When an excess of native insulin was injected together with the purified labeled hormone, the organ distribution of radioactivity was dramatically altered. Indeed, less was bound to the liver ( 14 vs. $37 \%$ at $3 \mathrm{~min}$ ), and more was associated with the kidneys and the carcass. The difference between the liver radioactivity in the presence and absence of an excess of native insulin probably reflected the activity of the liver insulin receptors. By comparison, in older pups (Fig. 5B), liver radioactivity decreased more rapidly after the 3rd min, and kidney radioactivity was higher.

Fig. 6 depicts the immediate postnatal variation of plasma IRI and blood glucose concentration in spontaneously delivered full-term pups. After a short rise during the first $15 \mathrm{~min}$ of extrauterine life, blood glucose concentration decreased and stabilized at $\cong 50 \mathrm{mg} / 100 \mathrm{ml} 90 \mathrm{~min}$ after birth. Plasma IRI concentration also slightly rose during the first minutes of extrauterine life, then decreased to approximately one-half of its value at birth. The same profile was observed in fetuses delivered by caesarian section $1 \mathrm{~d}$ before term. The premature pups only differed from their full-term mates by a lower blood glucose and a higher plasma IRI concentration during the first $30 \mathrm{~min}$ of extrauterine life. Thus, fetal hyperinsulinemia abruptly subsided at birth, even in premature pups in whom, had they remained in utero, hyperinsulinemia would 
TABLE III

Serum Radioactivity after Intravenous Injection of [ $\left.{ }^{125} \mathrm{I}\right]$ Monoiodoinsulin Alone or Mixed with an Excess of Native Insulin into 7- to 10-d-old Pups*

\begin{tabular}{|c|c|c|c|c|c|c|c|}
\hline \multirow[b]{3}{*}{$\begin{array}{l}\text { Sampling } \\
\text { time }\end{array}$} & \multicolumn{4}{|c|}{$\left[{ }^{125} \mathrm{I}\right]$ Monoiodoinsulin alone } & & & \\
\hline & \multicolumn{3}{|c|}{$\begin{array}{l}{[125 \mathrm{I}] \text { Monoiodoinsulin }} \\
\text { as identified by }\end{array}$} & \multirow[b]{2}{*}{${ }^{125} \mathrm{I}^{-}$} & \multicolumn{3}{|c|}{$\left[{ }^{125} I\right]$ Monoiodoinsulin + native insulin } \\
\hline & $\begin{array}{c}\text { Total } \\
\text { radio- } \\
\text { activity }\end{array}$ & $\frac{\text { as Iaen }}{\begin{array}{c}\text { Immunopre- } \\
\text { cipitation }\end{array}}$ & $\frac{\text { Gel chroma- }}{\text { tography }}$ & & $\begin{array}{l}\text { Total } \\
\text { radio- } \\
\text { activity }\end{array}$ & $\begin{array}{l}{\left[{ }^{125} \mathrm{I}\right] \text { Monoiodoinsulin }} \\
\text { as identified by } \\
\text { gel chromatography }\end{array}$ & ${ }^{125} I^{-}$ \\
\hline $\min$ & \multicolumn{7}{|c|}{$c p m / 100 \mu l$} \\
\hline 1 & 3,625 & 2,078 & 2,033 & ND $\ddagger$ & 7,560 & 6,647 & ND \\
\hline 3 & 2,225 & 997 & 970 & 190 & 4,519 & 3,575 & ND \\
\hline 6 & 2,150 & 519 & 540 & 549 & 2,941 & 2,217 & ND \\
\hline 9 & 1,950 & 350 & 234 & 697 & 2,217 & 1,571 & ND \\
\hline 12 & 1,836 & 255 & 146 & 737 & 2,130 & 1,338 & ND \\
\hline
\end{tabular}

* All values given are counts per minute per 100 microliters.

† Nondetectable.

have lasted one more day. This observation suggests that the factor that causes fetal hyperinsulinemia is not only extrapancreatic but also extrafetal and, possibly, placental.

The last experiment lends support to this hypothesis (Fig. 7). Pups were delivered by caesarian section $1 \mathrm{~d}$ before term, and the litter was divided into three groups. The pups of the first group were immediately
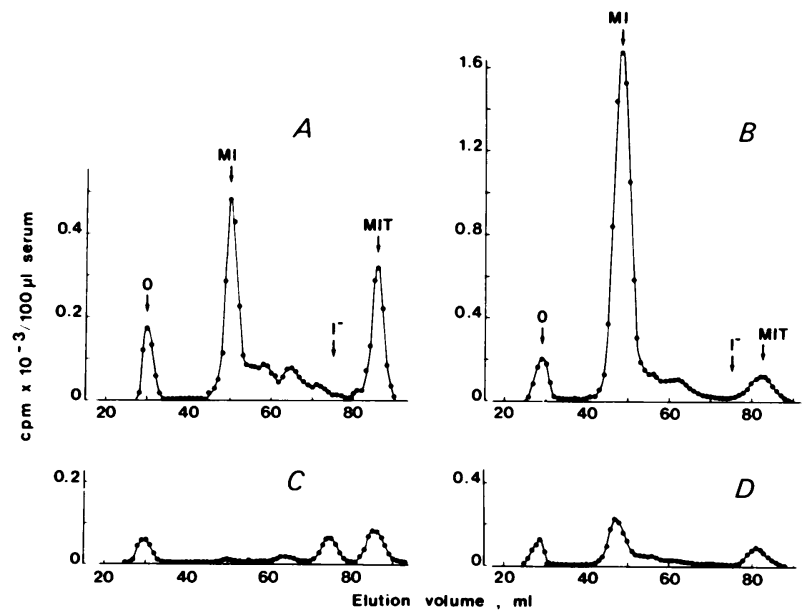

FIGURE 4 Elution pattern of serum radioactivity after an intravenous bolus injection of $\left[{ }^{125} \mathrm{I}\right]$ monoiodoinsulin alone or mixed with an excess of native insulin into fetuses. Serum samples $(0.2-0.4 \mathrm{ml})$ were applied on a $60 \times 1.2-\mathrm{cm} \mathrm{G50} \mathrm{F}$ Sephadex gel and eluted with $1 \mathrm{M}$ acetic acid at a rate of $2 \mathrm{ml} / \mathrm{h}$. 1-ml fractions were collected. The column was calibrated with albumin (external volume, 0), [125I]monoiodoinsulin (MI), ${ }^{125} \mathrm{I}^{-}\left(\mathrm{I}^{-}\right)$, and $\left.{ }^{127} \mathrm{I}\right]$ monoiodotyrosine (MIT). Fetuses, delivered $1 \mathrm{~d}$ before term were injected through the umbilical vein with the same amount of $\left.{ }^{[25} \mathrm{I}\right]$ monoiodoinsulin alone ( $\mathrm{A}$ and $C$ ) or mixed with an excess of native insulin (B and D). Serum samples were obtained $1 \mathrm{~min}(\mathrm{~A}$ and $\mathrm{B}$ ) and $12 \mathrm{~min}(\mathrm{C}$ and $\mathrm{D})$ after the injection. Note the difference of ordinate scales between the right and left panels. sacrificed. The cord of the pups of the second group was cut at birth. The pups of the third group remained attached to their placenta, and care was taken not to disturb fetal blood circulation through the cord and

\section{$A$}
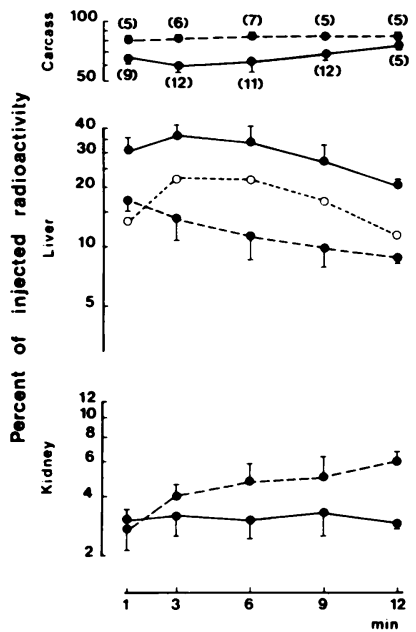

\section{$B$}
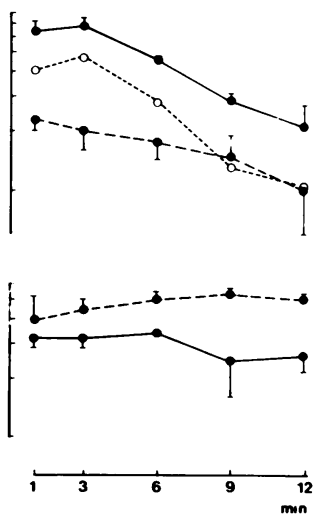

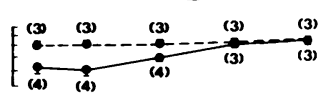

FiguRE 5 Organ distribution of radioactivity after the intravenous injection of [ $\left.{ }^{125} \mathrm{I}\right]$ monoiodoinsulin alone or mixed with an excess of native insulin into fetuses and nursing pups. Fetuses delivered by caesarian section $1 \mathrm{~d}$ before term $(\mathrm{A})$ and 7- to 10-d-old pups (B) received an intravenous injection of $0.006 \mu \mathrm{Ci} / \mathrm{g}$ body wt of [125I]monoiodoinsulin alone (solid lines) or mixed with $0.4 \mu \mathrm{g} / \mathrm{g}$ body wt native insulin (dashed lines). After sacrifice, the radioactivity of both kidneys (lower panels) of the liver (middle panels) and of the carcass (upper panels) was measured. Each point represents the mean, and the vertical bar represents $1 \mathrm{SD}$. The number of observations is indicated between parenthesis. Liver "specific binding" (open circles joined by a dotted line) was calculated by subtracting the radioactivity after the injection of a mixture of native and labeled insulin from that obtained after the injection of the labeled hormone alone. Note that the ordinate is in logarithmic scale. 


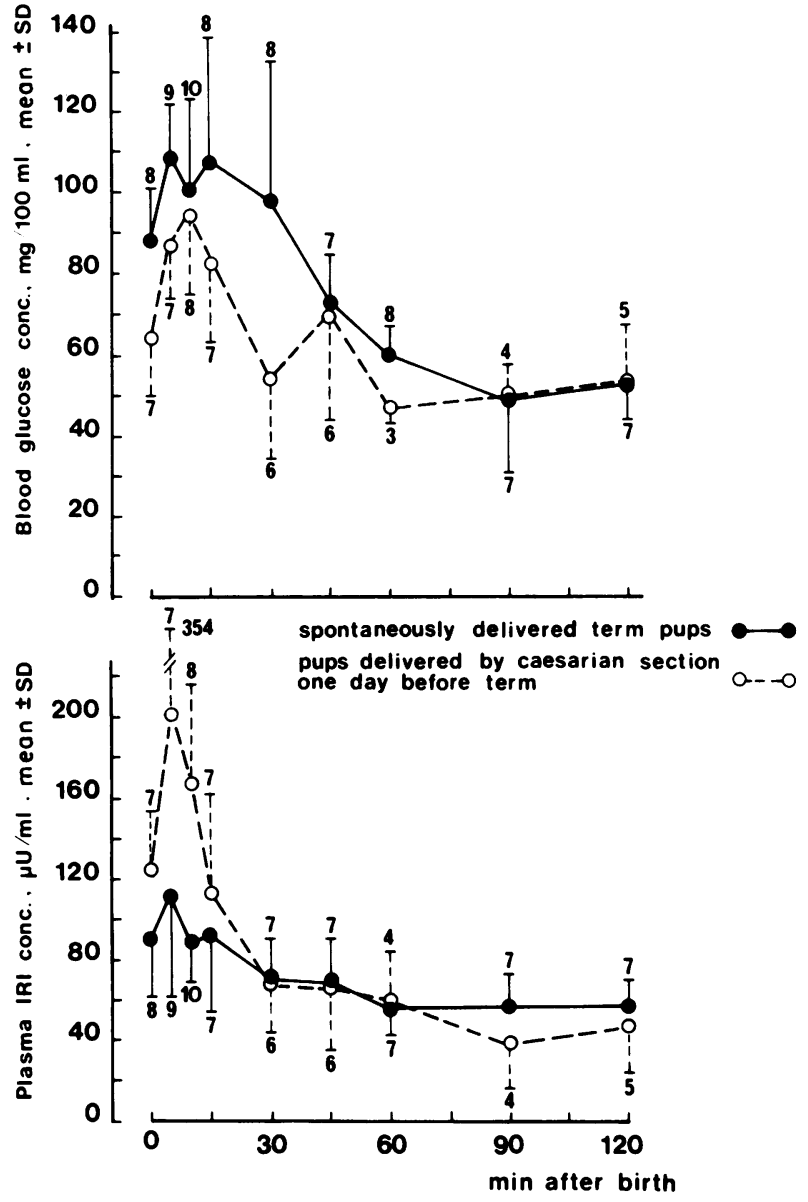

Figures 6 Postnatal variation of blood glucose and plasma IRI concentrations. Spontaneous delivery occurred under visual observation and premature pups were removed from their decapitated mother $1 \mathrm{~d}$ before full term. The pups were sacrificed at birth (time 0 ) or placed in a warm, humid, and oxygenated atmosphere until sacrificed. Each point represents the mean $(\odot$, full term pups; $\bigcirc$, premature pups), and the vertical bars represent $1 \mathrm{SD}$. The number of observations is indicated at the extremity of the bars. Conc., concentration.

placenta but the whole feto-placental unit was removed from the uterus. The pups of the last two groups were maintained at $37^{\circ} \mathrm{C}$ in a humidified, $\mathrm{O}_{2}$-enriched atmosphere and sacrificed after $30 \mathrm{~min}$. In the pups separated from their placenta, plasma IRI concentration decreased to less than one-half of its value at birth. By contrast, when the feto-placental unit was not severed, plasma IRI concentration remained at least as high as at birth. In this group, hyperinsulinemia caused a small but significant decrease in blood glucose concentration.

\section{DISCUSSION}

Rat fetal B-cell reactivity to glucose is still a debated matter. Several reports in which cultured pancreatic
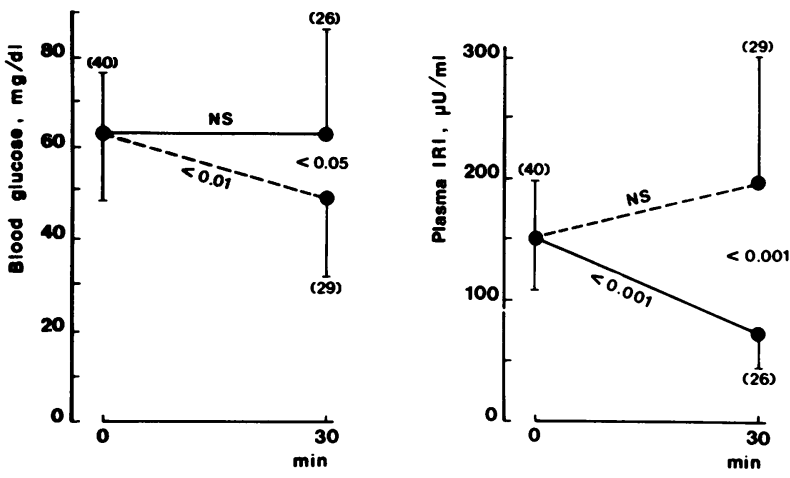

FIGURE 7 Effect of cord section on blood glucose and plasma IRI concentration of rat fetuses delivered by caesarian section $1 \mathrm{~d}$ before term. 40 premature pups were sacrificed at birth, 29 remained attached to their placenta (dashed lines), and 26 were separated from their placenta (solid lines). The last two groups were kept in a humidified, oxygenated, and warm atmosphere and sacrificed after $30 \mathrm{~min}$. The dots and vertical bars represent the mean $\pm 1 \mathrm{SD}$. Compared with its concentration at birth, plasma IRI concentration did not significantly change in the feto-placental units and markedly decreased in the fetuses separated from their placenta $(P<0.001)$. A significant decrease in blood glucose concentration also occurred in the feto-placental units.

explants (7), pancreatic pieces $(8,9)$, or isolated fetal (10) or neonatal (11) islets had been used supported the conclusion that glucose was not an insulinogenic agent before term. Other experiments suggested that the fetal B cells were not entirely glucose blind because phosphodiesterase inhibitors unmasked (10) or markedly enhanced (12) the secretagogue effect of glucose, and glucose alone was found capable of stimulating insulin biosynthesis (13). As opposed to these divergent results, experiments performed in vivo clearly demonstrated that a rise in fetal plasma glucose concentration induced a rise in plasma insulin concentration $(14,15)$. Discrepancies between these in vivo and in vitro results could not be satisfactorily explained except, possibly, by alterations of the incubated material or by differences in the neuroendocrine or metabolic environment between the two systems.

In this work, islets were isolated by very mild collagenase digestion and microdissection. This gentle method allowed us to harvest an adequate number of viable islets as early as $3 \mathrm{~d}$ before term. These islets proved suitable for studying the regulation of insulin and glucagon secretion (16). In particular, on the 19th $d$ of gestation they already exhibited a significant increase of IRI output when incubated in the presence of a high glucose concentration.

The metabolic clearance rate of insulin was estimated by injection of $\left[{ }^{125} \mathrm{I}\right]$ monoiodoinsulin into the umbilical vein of feto-placental units immediately followed by ligature of the cord. Results obtained with this experimental design do not necessarily apply to the fetus 
in utero because, in our experimental conditions, (a) fetal blood did not circulate through the placenta, (b) portal blood flow might be modified, and (c) plasma IRI concentration was not at a steady state.

Insulinase activity is particularly abundant in the placenta although it is not yet clearly established whether this enzyme activity is located on the fetal and(or) maternal side of the organ (17). Our experiments, however, clearly demonstrate that the overall effect of the placenta on fetal insulin economy is not to decrease but, on the contrary, to increase plasma insulin concentration.

Postnatal closure of the ductus venosus, which links the portal vein to the inferior vena cava, prevents part of the newly secreted insulin to bypass the liver. It is doubtful that this modification of portal blood flow is of major quantitative importance with regard to pancreatic hormone metabolism. If it were so, plasma IRI and glucagon concentrations would be expected to parallel each other. Actually, the concentrations of both hormones change in opposite directions after birth $(18,19)$.

Finally, as shown in Fig. 7, cord section induced changes of plasma IRI concentration would render precise calculation of the half-life of endogenous insulin hazardous.

Despite these limitations, our results indicate that insulin was rapidly cleared from the fetal plasma, even faster than in older pups (Fig. 3) or in adult rats. ${ }^{3}$ These results refute without any doubt the hypothesis that high fetal plasma insulin concentration is merely a result of accumulation of slowly metabolized hormone.

From the plasma, $\left[{ }^{125} \mathrm{I}\right]$ monoiodoinsulin was rapidly transferred to the peripheral tissue compartment (20), of which the liver appears to be the major component. Our finding of saturable insulin binding sites in the liver is in agreement with the results of Blazquez et al. (21) on isolated fetal liver cell membranes. Fetal kidney uptake of $\left[{ }^{125} \mathrm{I}\right]$ monoiodoinsulin was nonsaturable. In contrast with adult rat kidneys, which under the same experimental conditions would bind $15-20 \%$ of the injected tracer, ${ }^{4}$ fetal kidneys only bound $3 \%$ and nursing pups $7 \%$. Immature kidneys are indeed characterized by a decreased glomerular filtration rate, associated with proximal tubule immaturity, the latter causing increased insulinuria (22-24).

Little can be said about the activity of the insulindegrading enzymes during late fetal life. Compared with what is observed in older pups, the fetal liver radioactivity decreased more slowly, and the rate of appearance of free ${ }^{125} \mathrm{I}^{-}$in the plasma was more sluggish. This may reflect a slower rate of $\left[{ }^{125} \mathrm{I}\right]$ monoiodoinsulin degradation or, alternatively, of [ $\left.{ }^{125} \mathrm{I}\right] \mathrm{mono}-$

\footnotetext{
${ }^{3}$ Unpublished observations.

${ }^{4}$ Unpublished observations.
}

iodotyrosine deiodination. The latter hypothesis would be consistent with the known fetal liver immaturity with regard to iodotyrosine dehalogenase activity (25).

The precipitous fall in plasma IRI concentration which occurs at birth contrasts with the concomitant increase of insulin secretory capacity as estimated in vitro. This clearly indicates that, in vivo, extrapancreatic factors modulate insulin secretion. Because premature delivery induces the same variation of plasma IRI concentration as term delivery, delivery itself rather than maturation is the key event which eventually turns off insulin secretion in the newborn.

Fetal plasma corticosterone concentration increases in the immediate pre- and postnatal period (26). This steroid has been shown to inhibit insulin secretion, the degree of islet inhibition being related to the steroid concentration in the incubation medium (27). Stimulation of the adrenergic system has also been reported at birth (28). Although they may be operative and contribute to a postnatal inhibition of insulin secretion, these neuroendocrine modifications are transient and unable to explain the permanent change in insulin secretion rate which occurs at birth.

An alternate hypothesis should therefore be considered. Instead of a permanent postnatal inhibition of B-cell secretion, the possibility should be examined that, in utero, during late gestation, the $\mathrm{B}$ cells are under the influence of a secretagogue. Our experiments on prematurely delivered pups, connected to or severed from their placenta, strongly suggest that this B-cellstimulating factor exists and originates from the placenta. This hypothesis could also account for the findings of Portha et/al. (29) who reported that plasma IRI concentration was higher in postmature fetuses maintained in utero by progesterone injection to the pregnant rat than in borm pups of the same postcoital age.

If our hypothesis is correct, the metabolic status of the fetus and, in particular, glycogen storage in the liver, and growth of the insulin-sensitive tissues, would be controlled by a "placento-insular axis." At birth, when the cord is cut, the maternal fuel supply is interrupted and the newborn would be in great danger of becoming hypoglycemic if the factor which maintained hyperinsulinemia were not, fortunately, removed at the same time. Later, when the pups will be nursed, fuels and signals triggering insulin secretion will be provided by the gut.

\section{ACKNOWLEDGMENTS}

The secretarial assistance of Miss M. Fodor is gratefully acknowledged.

This work was supported in part by grants of the National Fund for Scientific Research, Brussels, Belgium.

\section{REFERENCES}

1. Blazquez, E., E. Montoya, and C. Lopez-Quijada. 1970. Relationship between insulin concentrations in plasma 
and pancreas of foetal and weanling rats. J. Endocrinol. 48: 553-561.

2. Felix, J. M., M. T. Sutter, B. Ch. J. Sutter, and R. Jacquot. 197.1. Circulating insulin and tissular reactivity to insulin in the rat during the perinatal period. Horm. Metab. Res. 3: 71-75.

3. Cohen, M. M., and R. C. Turner. 1972. Plasma insulin in the foetal rat. Biol. Neonatorum. 21: 107-111.

4. Hales, C. N., and P. J. Randle. 1963. Immunoassay of insulin with antibody precipitate. Biochem. J. 88: 137-146.

5. Lacy, P., and M. Kostianovski. 1967. Method for the isolation of intact islets of Langerhans from the rat pancreas. Diabetes. 16: 35-39.

6. Sodoyez, J. C., F. Sodoyez-Goffaux, M. M. Goff, A. E. Zimmerman, and E. R. Arquilla. 1975. [ $\left.{ }^{127} \mathrm{I}\right]$-or carrier-free [125I] monoiodoinsulin. Preparation, physical, immunological and biological properties and susceptibility to "insulinase" degradation. J. Biol. Chem. 250: 42684277.

7. Vecchio, D., A. Luyckx, and A. E. Renold. 1967. Culture d'organe de pancréas foetal de rat. II. Effets du glucose, d'un sulfamide hypoglycémiant et du glucagon sur la libération de l'insuline. Helv. Physiol. Pharmacol. Acta. 25: $134-146$.

8. Asplund, K., S. Westman, and C. Hellerström. 1969. Glucose stimulation of insulin secretion from the isolated pancreas of foetal and newborn rats. Diabetologia. 5: $260-262$.

9. Sodoyez-Goffaux, F., J. C. Sodoyez, and P. P. Foà. 1971. Effects of gestational age, birth and feeding on the insulinogenic response to glucose and tolbutamide by fetal and newborn rat pancreas. Diabetes. 20: 586-591.

10. Heinze, E., and J. Steinke. 1972. Insulin secretion during development: response of isolated pancreatic islets of fetal, newborn and adult rats to theophylline and arginine. Horm. Metab. Res. 4: 234-236.

11. Ågren, A., A. Andersson, and C. Hellerström. 1976. Effects of D-glyceraldehyde and D-glucose on the insulin release of pancreatic islets isolated from the newborn rat. FEBS (Fed. Eur. Biochem. Soc.) Lett. 71: 185-188.

12. Lambert, A. E., A. Junod, W. Stauffacher, B. Jeanrenaud, and A. E. Renold. 1969. Organ culture of fetal rat pancreas. I. Insulin release induced by caffeine and by sugars and some derivatives. Biochim. Biophys. Acta. 184: 529-539.

13. Asplund, K. 1973. Effects of glucose on insulin biosynthesis in foetal and newborn rats. Horm. Metab. Res. 5: 410-415.

14. Kervran, A., and J. R. Girard. 1974. Glucose-induced increase of plasma insulin in the rat foetus in utero. J. Endocrinol. 62: 545-551.

15. Blazquez, E., L. A. Lipshaw, M. Blazquez, and P. P. Foà. 1975. The synthesis and release of insulin in fetal, nursing and young adult rats: studies in vivo and in vitro. Pediatr. Res. 9: 17-25.

16. Sodoyez-Goffaux, F., J. C. Sodoyez, Cl. J. De Vos, and P. P. Foà. Insulin and glucagon secretion by islets isolated from fetal and neonatal rats. 1979. Diabetologia. 16: $121-123$.

17. Posner, B. I. 1973. Insulin metabolizing enzyme activities in human placental tissue. Diabetes. 22: 552-563.

18. Blazquez, E., T. Sugase, M. Blazquez, and P. P. Foà. 1974. Neonatal changes in the concentration of rat liver cyclic AMP and of serum glucose, free fatty acids, insulin, pancreatic and total glucagon in man and in the rat. J. Lab. Clin. Med. 83: 957-967.

19. Girard, J. R., A. Kervran, and R. Assan. 1975. Functional maturation of the A cell in the rat. In Early Diabetes in Early Life. R. A. Camerini Davalos and H. S. Cole, editors. Academic Press, Inc., New York. 57-71.

20. Zeleznik, A. J., and J. Roth. 1978. Demonstration of the insulin receptor in vivo in rabbits and its possible role as a reservoir for the plasma hormone. J. Clin. Invest. 61: $1363-1374$.

21. Blazquez, E., B. Rubalcava, R. Montesano, L. Orci, and R. H. Unger. 1976. Development of insulin and glucagon binding and the adenylate cyclase response in liver membranes of the prenatal, postnatal and adult rat: evidence of glucagon "resistance". Endocrinology. 98: 1014- 1023.

22. Schiff, D., and C. Lowy. 1970. Hypoglycemia and excretion of insulin in urine in hemolytic disease of the newborn. Pediatr. Res. 4: 280-285.

23. Chamberlain, M. J., and L. Stimmler. 1967. The renal handling of insulin. J. Clin. Invest. 46: 911-919.

24. Edelmann, C. M., and A. Spitzer. 1969. The maturing kidney. J. Pediatr. 75: 509-519.

25. Ingbar, S. H., and K. A. Woeber. 1974. The thyroid gland. In Textbook of Endocrinology. R. H. Williams, editor. W. G. Saunders Co., Philadelphia. 5th edition. 95-232.

26. Eguchi, Y., K. Arishima, Y. Morikawa, and Y. Hashimoto. 1977. Rise of plasma corticosterone concentrations in rats immediately before and after birth and in fetal rats after the ligation of maternal uterine blood vessels or of the umbilical cord. Endocrinol. Jpn. 100: 1443-1447.

27. McEvoy, R. C., O. D. Hegre, and A. Lazarow. 1976. Foetal rat pancreas in organ culture. Effect of corticosterone concentrations on the acinar and islet cell components. Differentiation. 6: 17-26.

28. Kervran, A., M. Gilbert, J. R. Girard, R. Assan, and A. Jost. 1976. Effect of environmental temperature on glucose-induced insulin response in the newborn rat. Diabetes. 11: 1026-1030.

29. Portha, B., G. Rosselin, and L. Picon. 1976. Postmaturity in the rat: impairment of insulin, glucagon and glycogen stores. Diabetologia. 12: 429-436. 